Folyóiratunk a jövőben meg kívánja ismertetni olvasóit egy-egy, a regionális tudomány "illetőségi területéhez" tartozó tudományos mühely tevékenységével. Elsóként egy "informális" - ezért feltehetöen kevéssé ismert - mühelyt, a fóváros fejlesztésével kapcsolatos témák vitafórumát, a Budapest Kört mutatja be spiritusz rektora, Tosics Iván.

\title{
Budapest Kör - szakmai vitafórum a városról
}

\section{Budapest Circle - a professional panel on the city}

\section{TOSICS IVÁN}

Immáron 14 éve, hogy 1997-ben egy tucatnyi szakértő, akik a városfejlődés különböző részleteihez értettek, egy fővárosi megbízás alapján elkezdtek együtt gondolkodni Budapest jövőjén. Eleinte nem volt könnyű, hogy a közlekedési szakember meghallgassa a szociális problémákról szóló fejtegetéseket, és viszont, majd mindketten a környezet, később pedig a kultúra állapotáról hallgassanak meg előadásokat. Hamar rájöttek azonban, hogy igenis szükséges kiszakadni a saját szakma kereteiből, és többféle szemszögből kell nézni a várost. Az elkészült mü - Budapest városfejlesztési koncepciója - kvalitásait 2003-ban, szokatlan módon, a Fővárosi Közgyűlés többórás szakmai vitájában mindegyik politikai oldal elismerte, és a koncepciót elfogadta.

A koncepciót követte a rövidebb távra, néhány évre szóló program kidolgozása, majd a munka egyre inkább eltolódott olyan projektek kidolgozásának irányába, amelyek EU-finanszírozásra esélyesek. Az átfogótól a minél konkrétabb dolgok felé haladás logikus, és szerencse, hogy ezek a szakaszok legalább részben egymásra épültek. Valami azonban elveszett közben: ahogyan egyre „szakmaibbak” lettek a feladatok, úgy oszlott fel a korábbi csapat, úgy ért véget a különböző tudású, érdeklődési körü emberek együtt gondolkodása.

2004. május 17-én a Padlás vendéglőben négyen összejöttünk a valamikori csapat tagjai közül, és elhatároztuk, hogy folytatjuk azt, ami a korábbi években jó volt, az egyes szakmák határait átlépő, közös gondolkodást. Elhatároztuk, hogy újra rendszeresen fogunk egymással találkozni, és folytatjuk a korábbi heves vitákat - még ha nem is egy konkrét munka keretei között. Ekkor alapítottuk meg a Budapest Kört. Eldöntöttük, hogy havonta találkozunk, minden

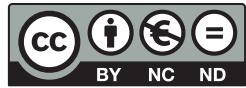


alkalommal egy konkrét témáról beszélünk. Nem „kifelé” akarunk látszani, hanem saját magunk igényeinek megfelelően müködni.

A Budapest Kör 2011. áprilisában a 70. találkozóját tartja, amiből könnyű kiszámolni, hogy a kezdeti elhatározás teljesült, és valóban rendszeresek a találkozók. A helyszín általában a Makadám Klub (Budán, a Millenáris parknál), és a korábbi „mag” egy része ma is állandó résztvevője a havonként egyszeri esti szeánszoknak.

A Budapest Kör specifikuma a tagság összetételének és érdeklődési körének sokszínüsége. Sokfajta szakma (építészet, várospolitika, közlekedés, gazdaság, ingatlanpolitika, városmenedzsment, szociális kérdések, várostörténet) képviselői vannak a Körben, és legtöbbjüket érdekli, ha a többi szakma valamelyike mutat be érdekes fejleményeket. A közös pont a Budapest, tágabban az európai nagyvárosok fejlődése és problémái iránti érdeklődés.

A Budapest Kör lényege tehát a sokszínűség, a különböző szakmák képviselőinek együtt gondolkodása. Amikor például az a téma, hogy mi lehetne Budapest „nagy dobása”, azaz mivel tűnhetne ki a többi európai város közül, akkor nem csupán ötletelés folyik, hanem hozzászól a történész arról, hogyan is zajlott ugyanez a vita 100 évvel ezelőtt, és mire jutottak akkor. A város és a vasút kapcsolatánál is előkerülnek a fővárosi pályaudvarok áthelyezésére vonatkozó, több évtizeddel ezelőtti elképzelések.

Jó néhány összejövetelt éles viták kísérnek, amelyek a végén olyan konklúziókra vagy éppen megválaszolatlan kérdésekre futnak ki, amelyek a vita előtt talán egyetlen résztvevőben sem fogalmazódtak meg az adott formában.

Ennek illusztrálására szolgálhat a Budapest Körnek az a találkozója, amely a város fejlesztésére az utóbbi száz évben készült koncepciókkal foglalkozott. Arra a megállapításra jutottunk, hogy az 1869-es első átfogó elképzelést sokkal kevésbé innovatív tervek követték, és még az 1970-es évek tervei is jóval beszűkültebbek voltak, pedig akkor sokkal nagyobb hatalom összpontosult a városvezetés kezében. Az utóbbi évszázad tehát adós maradt a modern városfejlődés növekedő problémáinak megválaszolásával, és erre a rendszerváltást követő másfél évtized sem volt képes.

Az EU-csatlakozással akár egy második „Gründerzeit”-re is lehetőség nyílt volna. Alapvető különbség ugyanakkor az 1870-es évekhez képest az országos politikai akarat hiánya a fơváros kiemelt fejlesztésére, továbbá az, hogy nincs egy olyan, a Fővárosi Közmunkák Tanácsához hasonló szervezet, amely a korrupció, illetve a széteső város fölé nőve irányítaná és egységesítené a fejlesztéseket. Ma alapvetően a magántőke építi a várost, ezért kulcskérdés a városvezetés elhivatottsága és beavatkozási készsége a piaci folyamatok tudatos terelésére, befolyásolására, Budapestet minimum a mai agglomeráció keretei között értelmezve.

Ha mindezek a feltételek meglennének, akkor is ott maradna a kérdés, hogyan lehetne a koncepcionális elképzeléseket érvényesíteni a mai politikai, szabályozási, gazdasági környezetben? Miután alapvető refor- 


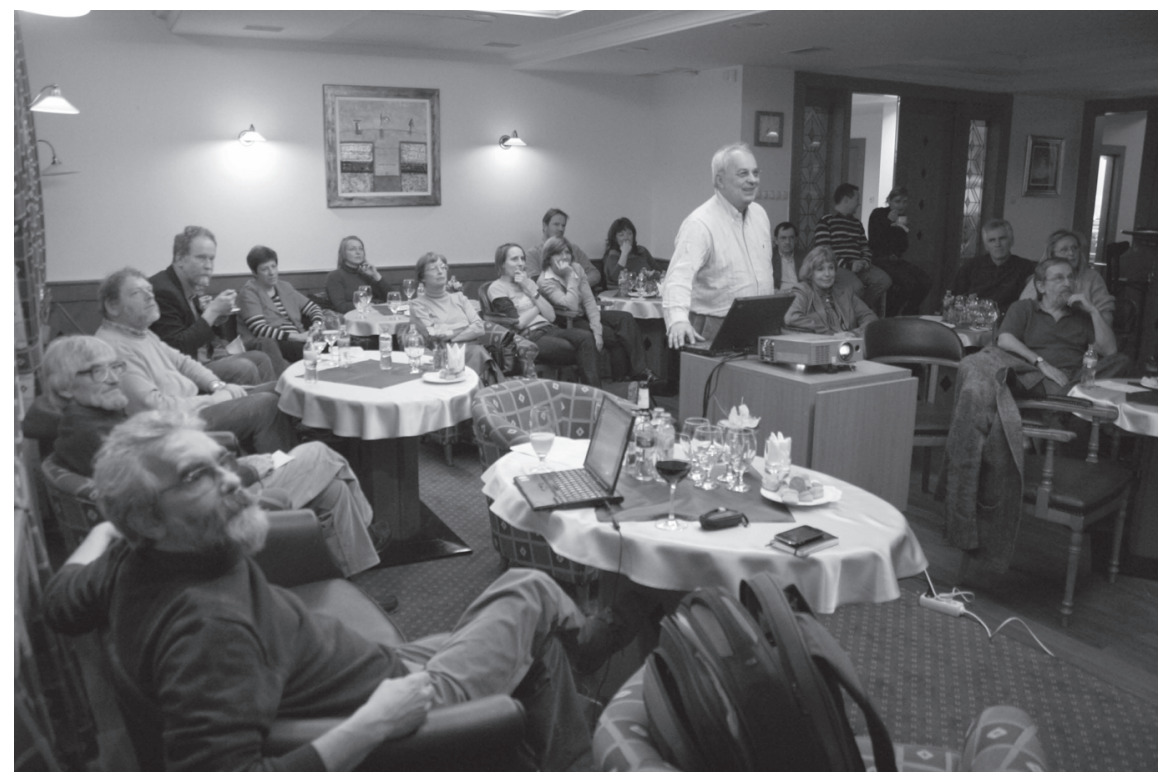

mokra (a kerületek szerepének gyengítésére, a fővárosi vagyon központosítására, a városkörnyéki települések feletti ellenőrzés megszerzésére) nincs lehetőség, pótmegoldásokat lehetne csak alkalmazni. Ezek a politikai és gazdasági előnyökkel kecsegtető önkéntes kooperációk kialakításán, vonzóvá tételén alapulhatnának. Kerületi és városkörnyéki politikai vezetőkkel való rendszeres konzultáció, a kistérségi (regionális) kooperáció gazdaságfejlesztési elemeinek (közös tulajdonban lévő fejlesztési társaság, közös koncepciók és marketing) megteremtése lehetne a járható út. Az együttműködés esetén minden szereplő által elérhető nagyobb nyereséget kellene felvillantani és vonzóvá tenni a szembenállás, illetve együtt-nem-működés opciójához képest.

Ezek a mai realitások ismeretében eléggé irreális feltételezések, és teljesülésük esetén sem vezethetnének tartós sikerre az adminisztratív struktúra és szabályozási környezet átalakítása hiányában. Így már csak egyetlen megoldás maradna: a nagy projekteket, programokat ki kellene venni a normál ügymenetből (ahogyan az száz éve is szokás volt, l. pl. Bárczy-program). Érvényesülnie kellene a Business Improvement District alapgondolatának, miszerint egy adott terület fejlesztése értéknövekedéshez vezet, amelynek egy részét adókon keresztül a közszférának kellene megkapnia. Ennek megvalósítását azonban bonyolítja a kétszintű fővárosi rendszer, de egyébként sincsenek meg a jogszabályi feltételei.

$\mathrm{Az}$ általános, koncepcionális kérdések mellett sokszor került sor konkrét városfejlesztési dilemmák megvitatására. 
- A budai alsó rakpart történetének megvitatásakor bemutatták a 2×2 sávos kiépítést, majd a tiltakozások hatására kialakított alagutas megoldást is. A több éven keresztül húzódó vita során érdekesen ütközött a minőséget tartani akaró műemlékes és a „ha már építkezünk, akkor minél több le- és felhajtót tegyünk bele" típusú műszaki elképzelés. Végül a szakma nem tudott egyetérteni, a fơvárosi önkormányzatnál sem volt egységes vélemény (aktív projektmenedzsment sem), nem volt meg az elfogadhatónak tartható megoldáshoz szükséges pénz, a kapcsolódó EU-program miatt pedig olyan időkényszer alakult ki, ami nem tette lehetővé a kiérlelő vitát. Mindezek mellett a zöldek senkiben sem hittek... nem volt olyan koncepciózus erő, amelyik kellő hosszúságú és időben tartott vita után meg merte volna hozni a döntést, és azt egységesen fellépve végre is hajtotta volna. A rakpart története jól mutatja a város és az ország állapotát az ezredfordulón, mindenféle vonatkozásban.

- A kreatív és kulturális gazdaságról (a Szimplakertben) lefolytatott vita rámutatott, hogy a kreatív kulturális és a kreatív gazdasági vállalkozások sokat segíthetnek egy térség gettósodásának feloldásában. Ezek ugyanakkor eltérő támogatást igényelnek, előbbinek terek, helyek kellenek, utóbbinak inkább az indulási feltételek folyamatosságának biztosítása. Nem könnyü a közösségi szektor megfelelő szerepét kialakítani - a kreatív kulturális helyek esetében például a lokációs potenciált lehetne erősíteni, megakadályozva, hogy a piaci folyamatok kiszorító hatása teljes mértékben érvényesüljön.

- A posztszocialista városfejlődésről folytatott vita során merült fel a modernizációs nyomás és a megőrzés dilemmája. Amikor megvesszük a mások által használtat vagy a nagyon újat, egyikkel sem a sajátunkat őrizzük és újítjuk meg. Ezt talán éppen a villamosok példáján lehet jól illusztrálni: egyetlen tanácsadó sem javasolja, hogy a sajátunkat felújítsuk, mind az ő új vagy régi dolgait ajánlja. A hannoveri villamos, illetve a Combino alternatívája az 50 éves Ganz-villamosok felújítása lett volna (amihez persze több város összefogása és erős közösségi akarat kellett volna, még a villamosgyártásra képes üzem megszűnése előtt).

A Budapest Kört informális jellege ellenére komolyan veszik az úgynevezett „fontos” emberek is. Előfordult, hogy a város frissen kinevezett föpolgármester-helyettese néhány középtávú fejlesztési elképzelést vetett fel, és részt vett ezek vitáján. Többször is sor került a város foeépítészének a „konzultációjára" is a kör tagjaival, városfejlesztési prioritások vagy éppen városrendezési eljárások témakörében. Meghívásra eljön ide kerületi polgármester, cégigazgató, minisztériumi tisztségviselő. Érzik, hogy ebben az interdiszciplináris társaságban érdekes és új szempontok felvetésére számíthatnak, és arra is, hogy széles körü szakmai alapokon álló véleményekkel gazdagodhatnak. 
A Budapest Kör tagjai ugyanakkor minden vitát a szakmaiság keretei között akarnak tartani, és elkerülik konkrét politikai viták véleményezését. Egy kivétel volt eddig: a kormányzati negyed kapcsán a Budapest Kör interneten nyilatkozatot tett közzé.

Évek óta napirenden van az a kérdés, hogy milyen módon váljanak közkinccsé az érdekes viták eredményei - mi értelme az egésznek, ha mások nem értesülhetnek ezekről? A kérdés jogos, a nyilvánosság elé való kilépés azonban egyáltalán nem könnyü. A Budapest Kör egyelőre tartja zárt jellegét (ami egyben garancia arra, hogy itt mindenki nyíltabban beszélhet). Nincs kizárva azonban, hogy jól megírt vita-összefoglalók nyilvánossá váljanak, mint ahogy a Budapest folyóiratban már meg is jelent néhány. A tervek között szerepel évenkénti összefoglaló készítése arról, mik voltak a legizgalmasabb viták az adott évben.

A Budapest Kör szívesen fogad tagjai közé olyan szakembereket, akik e rövid írás alapján kedvet kaptak a város problémáiról és lehetőségeiről való rendszeres vitatkozásra. Jelentkezni a Budapest Kör titkáránál, Tosics Ivánnál lehet: tosics@mri.hu 